\title{
Immunity of the Fe-N-C catalysts to electrolyte adsorption: phosphate but not perchloric anions
}

Hu, Yang; Jensen, Jens Oluf; Pan, Chao; Cleemann, Lars Nilausen; Shypunov, Illia; Li, Qingfeng

Published in:

Applied Catalysis B: Environmental

Link to article, DOI:

10.1016/j.apcatb.2018.03.056

Publication date:

2018

Document Version

Peer reviewed version

Link back to DTU Orbit

Citation (APA):

Hu, Y., Jensen, J. O., Pan, C., Cleemann, L. N., Shypunov, I., \& Li, Q. (2018). Immunity of the Fe-N-C catalysts to electrolyte adsorption: phosphate but not perchloric anions. Applied Catalysis B: Environmental, 234, 357364. https://doi.org/10.1016/j.apcatb.2018.03.056

\section{General rights}

Copyright and moral rights for the publications made accessible in the public portal are retained by the authors and/or other copyright owners and it is a condition of accessing publications that users recognise and abide by the legal requirements associated with these rights.

- Users may download and print one copy of any publication from the public portal for the purpose of private study or research.

- You may not further distribute the material or use it for any profit-making activity or commercial gain

- You may freely distribute the URL identifying the publication in the public portal 
Catalysis B: Environmental

Elsevier Editorial System(tm) for Applied Manuscript Draft

Manuscript Number:

Title: Immunity of the Fe-N-C catalysts to electrolyte adsorption: phosphate but not perchloric anions

Article Type: Research Paper

Keywords: oxygen reduction; catalyst; fuel cell; anion; poison

Corresponding Author: Dr. YANG HU,

Corresponding Author's Institution: Technical University of Denmark

First Author: YANG HU

Order of Authors: YANG HU; Jens Oluf Jensen, Prof.; Chao Pan; Lars Nilausen Cleemann; Illia Shypunov; Qingfeng Li, Prof. 


\title{
Immunity of the Fe-N-C catalysts to electrolyte adsorption: phosphate but not perchloric anions
}

\author{
Yang Hu,* Jens Oluf Jensen, Chao Pan, Lars Nilausen Cleemann, Illia Shypunov, Qingfeng Li* \\ Department of Energy Conversion and Storage, Technical University of Denmark, Kemitorvet 207, \\ DK-2800 Kgs. Lyngby, Denmark.
}

Corresponding authors: a. Yang Hu, E-mail: yanhu@dtu.dk, Tel.: +45 45252327

b. Qingfeng Li, E-mail: qfli@dtu.dk. Tel.: +45 45252318

\begin{abstract}
:
Non-precious metal catalysts (NPMCs), particularly the type based on carbon-supported $\mathrm{FeN}_{\mathrm{x}}$ functionalities $(\mathrm{Fe}-\mathrm{N}-\mathrm{C})$ are a very promising material for replacing the rare and costly platinum-based catalysts in polymer electrolyte membrane fuel cells (PEMFCs). Evaluation of these materials is most often carried out, like for Pt-based catalysts, in dilute perchloric acid by assuming its non-adsorbing nature on the active sites. The assumption is however not true. In this work, a typical Fe-N-C catalyst was first synthesized by high-pressure pyrolysis in the presence of carbon support and thoroughly characterized in terms of morphology, structure and active site distribution. The subsequent electrochemical characterization of the catalyst shows strong adsorption and poisoning effect of, in addition to the known $\mathrm{Cl}^{-}$, perchloric anions on the oxygen reduction reaction (ORR) activity. On the contrary phosphate anions exhibit negligible poisoning effect on the catalyst activity. At a potential of $0.8 \mathrm{~V}$ vs. RHE, the ORR activity of the catalysts is found to decrease in the order of $\mathrm{H}_{3} \mathrm{PO}_{4}\left(8.6 \mathrm{~mA} \mathrm{mg}^{-1}\right)>\mathrm{HClO}_{4}\left(3.1 \mathrm{~mA} \mathrm{mg}^{-1}\right)>\mathrm{HCl}\left(0.69 \mathrm{~mA} \mathrm{mg}^{-1}\right)$. The results suggest potential applications of NPMC in high-temperature PEMFCs based on phosphoric acid doped polymer membranes, where high loading platinum catalysts are currently used. As demonstrated in the low current density range of high-temperature PEMFCs, the catalyst shows a comparable performance to the $\mathrm{Pt} / \mathrm{C}$ catalysts.
\end{abstract}


Keywords: oxygen reduction, catalyst, fuel cell, anion, poison

\section{Introduction:}

Energy is undoubtedly one of the most key elements for a sustainable society. The transition from fossil fuels to renewable energy sources has been an on-going process for many countries due to the increasing demands in energy consumption and the concern of the environmental deterioration. Recently, several countries such as Germany, Norway, and France have announced different timetables for a ban on sales of fossil fuel cars.[1] China, which has the world's largest car market, as reported recently, is currently developing a timetable for a similar ban.[2] Obviously, in the future, techniques that can produce, convert or store renewable energy will play a more significant role in our societies.

Fuel cells are a highly efficient and environmentally benign technology to convert chemical energy directly into electric energy. Among several types of fuel cells under active development, the polymer electrolyte membrane fuel cell (PEMFC) is regarded as a promising power source for fossil fuel-free cars and other portable or stationary applications. [3, 4] Thus far, platinum-based nanocatalysts are the state-of-the-art for both the anode and cathode of PEMFCs. However, the high cost and limited availability of platinum are a big issue for the wide adoption of this technology.[5, 6] Besides, regarding high-temperature PEFMCs that typically employ a phosphoric acid-doped polybenzimidazole (PBI) membrane, the strong adsorption of phosphates on platinum is another major issue, which significantly decreases the catalyst activity and the overall cell performance.[7,8] In order to replace platinum-based catalysts in PEFMCs, especially on the cathode side, various non-precious metal catalysts (NPMCs) have been developed. Among them, composite materials comprising porous carbon supported $\mathrm{Fe}-\mathrm{N}$ functionalities (referred to as $\mathrm{Fe}-\mathrm{N}-\mathrm{C}$ catalysts) exhibit the best activity, which are typically synthesized by pyrolyzing precursors containing iron, nitrogen, and carbon at temperatures ranging from 600 to $1000{ }^{\circ} \mathrm{C}$. [9-13]

The state-of-the-art PEMFC performance based on Fe-N-C catalysts matches that of Pt/C at low and even medium current densities, though the needed catalyst loading is typically 3-6 times higher.[14, 15] At the cell voltage of $0.8 \mathrm{~V}$, the performance of the type catalysts, by extrapolating from the 
Tafel plot, was reported to reach a volumetric current density of $99 \mathrm{~A} \mathrm{~cm}^{-3}$ at 2009 [16] and $230 \mathrm{~A}$ $\mathrm{cm}^{-3}$ at 2011 [17]. The recent breakthrough was from a MOF-based nanofibrous catalyst, which showed the activity of $450 \mathrm{~A} \mathrm{~cm}^{-3}$ at the cell voltage of $0.8 \mathrm{~V}$, which exceeded the newly updated 2017/2020 U.S. Department of Energy (DOE) target of $300 \mathrm{~A} \mathrm{~cm}^{-3}$.[15]

Like for platinum-based catalysts, the NPMC is often evaluated by the rotating disk electrode test using dilute perchloric acid as the electrolyte. As sulfate and phosphate anions are well known to adsorb on Pt, [18-21] perchloric acid is considered to be a non-adsorbing or weakly adsorbing electrolyte that has been used to simulate the role of Nafion ionomer in PEMFCs.[22, 23] Trace contaminations in the testing $\mathrm{HClO}_{4}$ electrolyte such as chloride, sulfate, nitrate in ppb to ppm levels show significant effects on the ORR activity of the Pt catalysts.[21, 23-27] It is, therefore, a general practice in the electrochemical characterization of ORR catalysts that cell glassware, rotator shafts, electrode tips and electrolytes undergo a very careful cleaning procedure to avoid these impurities.

For Fe-N-C catalysts, they are always assumed to be immune to the perchloric anions and characterized in dilute perchloric acid. $[13,28]$ Other anions, except for the strongly Fe-chelating species such as $\mathrm{CN}^{-}$and $\mathrm{SCN}^{-}$[18-21], have not been carefully investigated on the ORR performance of Fe-N-C catalysts. This work is devoted to such a study focusing on common anions including $\mathrm{ClO}^{-}, \mathrm{Cl}^{-}$, and $\mathrm{H}_{2} \mathrm{PO}_{4}^{-}$. The chloride ion is a common impurity originating from contaminations of electrolyte, glassware and reference electrodes such as saturated calomel electrode (SCE) or $\mathrm{Ag} / \mathrm{AgCl}$ electrode. [29, 30] Phosphate is of special interest as the acid and its doped polymer membrane are electrolyte for phosphoric acid fuel cells (PAFC) and high-temperature PEMFCs. [31] These cells are currently based on platinum catalysts at a significantly higher loading, as a consequence of the strong phosphate adsorption of the platinum surface.[32] It is, therefore, a more critical issue for evaluation and utilization of NPMCs in PAFC and HT-PEMFCs. In this regard, Li et al. studied the effect of phosphate ions on the catalytic activity in $\mathrm{HClO}_{4}$ and reported good tolerance of an Fe-derived catalyst at concentrations of up to $5.0 \mathrm{M} \mathrm{H}_{3} \mathrm{PO}_{4}$.[33]

In this work, a typical Fe-N-C catalyst was first synthesized by high-pressure pyrolysis in the presence of carbon support and characterized in terms of the morphology, structure and active site distribution. The catalyst was then used to probe the effect of three common anions, i.e. $\mathrm{ClO}^{-}$, 
$\mathrm{H}_{2} \mathrm{PO}_{4}{ }^{-}$and $\mathrm{Cl}^{-}$on the ORR performance. It was found, in addition to $\mathrm{Cl}^{-}$, the $\mathrm{ClO}_{4}{ }^{-}$anion also had a strong poisoning effect on the active sites of the Fe-N-C catalyst, raising an issue of electrolytes for the NPMC evaluation. The adsorption of $\mathrm{H}_{2} \mathrm{PO}_{4}{ }^{-}$anions was, on the other hand, negligible on the catalyst. As a result, the catalyst exhibited a better catalytic activity towards the ORR in phosphoric acid than in perchloric acid, which indicated its promising application in high-temperature PEMFCs. As demonstrated, the catalyst did show excellent performance in high-temperature PEFMC tests, which, in the low current density range, is comparable to $\mathrm{Pt} / \mathrm{C}$ catalysts.

\section{Experimental:}

Catalyst synthesis: The catalyst (named as BP-FeNC hereafter) was synthesized by pyrolyzing precursors including cyanamide $\left(\mathrm{NH}_{2} \mathrm{CN}, 99 \%\right.$, Sigma-Aldrich), ferrocene $\left(\mathrm{Fe}\left(\mathrm{C}_{5} \mathrm{H}_{5}\right)_{2}, 98 \%\right.$, Sigma-Aldrich) and Black Pearls 2000 carbon black (BP, CABOT) at $750{ }^{\circ} \mathrm{C}$ in an autoclave (made from stainless steel, $2.3 \mathrm{~mL}$ ). Specifically, first, $300.1 \mathrm{mg}$ of cyanamide, $33.7 \mathrm{mg}$ of ferrocene and $51.2 \mathrm{mg}$ of BP were thoroughly mixed and transferred into a quartz holder. It was then put into an autoclave and moved into an Ar-filled glove box and closed there. After that, the autoclave was taken out of the glovebox and placed in a tube-furnace with Ar flow for the heat-treatment (the Ar flow was for protecting the autoclave from oxidation at high temperatures). The tube furnace was heated from room temperature to $750{ }^{\circ} \mathrm{C}$ at a rate of $10{ }^{\circ} \mathrm{C} \mathrm{min}^{-1}$ and maintained at $750{ }^{\circ} \mathrm{C}$ for 1 hour, after which the autoclave was moved away from the heating zone to achieve fast cooling. After opening the autoclave at room temperature, a black powder of 38.0 wt $\%$ of the initial precursors was collected, which meant, apart from the BP, $65.3 \mathrm{wt} \%$ of the product was newly formed phases from the precursor. The product was leached in $1.0 \mathrm{M} \mathrm{H}_{2} \mathrm{SO}_{4}$ solution at room temperature in an ultrasonic bath for 5 hours to remove unstable phases, and then it was washed thoroughly with Milli-Q water (close to $100{ }^{\circ} \mathrm{C}$ ) and dried at $95{ }^{\circ} \mathrm{C}$ for 5 hours. At last, the catalyst was heat-treated again in $\mathrm{Ar}$ flow $(99.999 \%)$ at $800{ }^{\circ} \mathrm{C}$ for 1 hour.

Physical characterizations: Transmission electron microscope (TEM) and high-angle annular dark-field scanning transmission electron microscopy (HAADF-STEM) images were obtained with an FEI Titan Analytical 80-300ST TEM at $300 \mathrm{kV}$. Nitrogen sorption isotherms were measured at 77 K with a Micromeritics ASAP 2020. Before the analysis, the catalysts were degassed in vacuum at 
$200{ }^{\circ} \mathrm{C}$ for $24 \mathrm{~h}$. The surface area was determined using the BET method based on adsorption data in the relative pressure $\left(\mathrm{P} / \mathrm{P}^{0}\right)$ range of 0.06 to 0.14 . The pore size distribution was determined using the BJH method. Powder X-ray diffraction (XRD) measurements were performed with a MiniFlex 600 X-ray diffractometer (Rigaku) using a $\mathrm{Cu} \mathrm{K \alpha}(\lambda=1.5405 \AA$ ) radiation source. X-ray photoelectron spectroscopy (XPS) measurements were carried out on a Thermo Scientific ${ }^{\mathrm{TM}} \mathrm{K}-\mathrm{Alpha}+\mathrm{TM}$ X-ray Photoelectron Spectrometer (XPS) with an Al Ka X-ray monochromator. Survey scans were obtained using a pass energy of $200 \mathrm{eV}$, while high-resolution scans of specific elements were obtained using a $50 \mathrm{eV}$ pass energy. The binding energy shift was checked by carrying out a valence scan. Data quantification was performed using the Avantage program. Inductively coupled plasma-optical emission spectroscopy (ICP-OES) analysis was conducted using a Varian Vista-MPX. For the ICP-OES analysis, the BP-FeNC catalyst was first heated in air flow at $700{ }^{\circ} \mathrm{C}$ to remove the carbon component. The residue was then dissolved in a mixture of trace metal-grade concentrated hydrochloric and nitric acids, which was diluted with Milli-Q water for the analysis.

Electrochemical measurements: Electrochemical measurements were conducted using a VSP multichannel potentiostat from Biologic. The $\mathrm{pH} 1.0 \mathrm{HClO}_{4}, \mathrm{H}_{3} \mathrm{PO}_{4}$ and $\mathrm{HCl}$ solutions were prepared by diluting high-purity concentrated chemicals, i.e., $\mathrm{HClO}_{4}\left(70 \%\right.$, Aldrich), $\mathrm{H}_{3} \mathrm{PO}_{4}(\geq 85 \%$, Fluka) and $\mathrm{HCl}$ (37\%, Sigma-Aldrich), respectively. BP-FeNC catalyst inks were prepared by ultrasonically dispersing $5.0 \mathrm{mg}$ catalyst in a solution consisting of $40 \mu \mathrm{L}$ Nafion (5 wt \%) and $385.17 \mu \mathrm{L}$ formic acid ( $\geq 95 \%$ ). Pt/C catalyst inks (20 wt\%, from Johnson Matthey) was prepared by dispersing $5 \mathrm{mg}$ of catalyst in a solution of $2460 \mu \mathrm{L}$ formic acid ( $\geq 95 \%), 50 \mu \mathrm{L}$ Nafion (5 wt \%) and $40 \mu \mathrm{L}$ Milli-Q water. A specific amount of ink was cast onto a rotating disk electrode (RDE, $0.196 \mathrm{~cm}^{2}$, Pine Research Instrumentation) or rotating ring-disk electrode (RRDE) $\left(0.196 \mathrm{~cm}^{2}\right.$, Pine Research Instrumentation) to reach the required catalyst loading. A standard three-electrode cell was employed for the measurements, which incorporated the RDE/RRDE as the working electrode, a graphite rod (99.995\% trace metals basis) as the counter electrode and a daily prepared reference hydrogen electrode (RHE) as the reference electrode. The filling electrolyte in the RHE was the same as that in the main compartment, which avoided the possible contamination from the reference electrode as in $\mathrm{SCE}$ or $\mathrm{Ag} / \mathrm{AgCl}$ electrode. The RHE was calibrated before each test. Both the reference electrode and counter electrode were separated from the working electrode compartment using porous glass 
frits. All glassware was cleaned in Piranha solution and rinsed with hot Milli-Q water at least three times before use. Ultra-high purity $\mathrm{O}_{2}(99.999 \%)$ and $\mathrm{Ar}(99.999 \%)$ were used in the measurements. All ORR curves have been corrected for the capacitance current and the solution resistance, with the latter being measured by electrochemical impedance spectroscopy (EIS), which was recorded at open circuit potential by applying an AC signal with $10 \mathrm{mV}$ amplitude over the frequency range from 100 $\mathrm{kHz}$ to $0.1 \mathrm{~Hz}$. Tafel plots shown in Figure $3 \mathrm{~b}$ and $3 \mathrm{e}$ were calculated from the corresponding ORR polarization curves after the mass-transport correction by the equation

$$
\frac{1}{i}=\frac{1}{i_{k}}+\frac{1}{i_{l}}
$$

, where $i_{k}$ is the kinetic current density, $i_{l}$ is the diffusion limiting current density, and $i$ is the measured current density. For the consistency, in this work, $i_{l}$ was defined as the current density at $0.3 \mathrm{~V}$ for each curve. Regarding RRDE tests, the ring potential was held at $1.2 \mathrm{~V}$, while the disc potential was scanned. The $\mathrm{H}_{2} \mathrm{O}_{2}$ collection coefficient for the ring was 0.254 , determined by measurements in a $\mathrm{K}_{3} \mathrm{Fe}(\mathrm{CN})_{6}$ solution, in good agreement with the manufacturer value. The following equation was used to calculate the $\% \mathrm{H}_{2} \mathrm{O}_{2}$ (the percentage of $\mathrm{H}_{2} \mathrm{O}_{2}$ released during ORR),

$$
\% \mathrm{H}_{2} \mathrm{O}_{2}=100 \frac{2 \mathrm{I}_{\mathrm{R}} / \mathrm{N}}{\mathrm{I}_{\mathrm{D}}+\left(\mathrm{I}_{\mathrm{R}} / \mathrm{N}\right)}
$$

where $I_{D}$ is the Faradaic current at the disk, $I_{R}$ the Faradaic current at the ring and $\mathrm{N}$ is the $\mathrm{H}_{2} \mathrm{O}_{2}$ collection coefficient at the ring. All measurements were carried out at room temperature. Considering the following equilibria for $\mathrm{H}_{3} \mathrm{PO}_{4}$ solutions,

$$
\begin{aligned}
& \mathrm{H}_{3} \mathrm{PO}_{4}+\mathrm{H}_{2} \mathrm{O} \rightleftharpoons \mathrm{H}_{3} \mathrm{O}^{+}+\mathrm{H}_{2} \mathrm{PO}_{4}^{-}\left(\mathrm{pK}_{\mathrm{a} 1} \approx 2.16\right)(3) \\
& \mathrm{H}_{2} \mathrm{PO}_{4}^{-}+\mathrm{H}_{2} \mathrm{O} \rightleftharpoons \mathrm{H}_{3} \mathrm{O}^{+}+\mathrm{HPO}_{4}^{2-}\left(\mathrm{pK}_{\mathrm{a} 2} \approx 7.21\right)(4) \\
& \mathrm{HPO}_{4}^{2-}+\mathrm{H}_{2} \mathrm{O} \rightleftharpoons \mathrm{H}_{3} \mathrm{O}^{+}+\mathrm{PO}_{4}^{3-}\left(\mathrm{pK}_{\mathrm{a} 3} \approx 12.32\right)(5)
\end{aligned}
$$

in the present study with acidic media, only $\mathrm{H}_{2} \mathrm{PO}_{4}{ }^{-}$is of significance. $\mathrm{HPO}_{4}{ }^{2-}$ will be dominantly present in neutral while $\mathrm{PO}_{4}{ }^{3-}$ is present in basic media. 
Fuel cell tests: Catalyst inks were prepared by mixing the catalyst (BP-FeNC, 60 wt \% Pt/C or 20 wt \% Pt/C) with a specific amount of PBI/formic acid solution, with the details shown in Table 1. The gas diffusion layer (GDL) was Freudenberg H2315, a commercial carbon cloth coated with a carbon microporous layer (MPL) on one side. The cathodes were prepared by spraying the catalytic ink over the MPL. The anodes were commercial Pt-based electrodes with a loading of $1.6 \mathrm{mg}_{\mathrm{Pt}} \mathrm{cm}^{-2}$ from Danish Power Systems. The membrane electrode assemblies (MEAs) were constructed by assembling an $\mathrm{H}_{3} \mathrm{PO}_{4}$-doped PBI membrane (80 $\mu \mathrm{m}$ thick, polymer molecular weight of ca. 78000) between the electrodes without hot pressing. A single high-temperature PEMFC cell was used for all the tests, which had an active area of $1 \mathrm{~cm}^{2}$. Polarization curves were recorded by scanning the cell voltage from OCV down to $0.1 \mathrm{~V}$ at a scan rate of $1 \mathrm{mV} \mathrm{s}^{-1}$ using the staircase cyclic voltammetry. Given that the focus of fuel tests was on the catalyst performance evaluation, $\mathrm{O}_{2}$, instead of air, was used. All the tests were carried out at ambient pressure and $160{ }^{\circ} \mathrm{C}$ with non-humidified gasses $\left(\mathrm{H}_{2} / \mathrm{O}_{2}\right)$.

\section{Results and discussion:}

The BP-FeNC catalyst was synthesized by pyrolyzing cyanamide, ferrocene, and BP in an autoclave at $750{ }^{\circ} \mathrm{C}$. The morphology and structure of the catalyst are shown in Figure 1. As revealed by the SEM image (Figure 1a), it has a similar morphology to BP (Figure S1), consisting of mainly sub-100 $\mathrm{nm}$ particles. Typical TEM (Figure 1b) and HAADF-STEM (Figure 1c) images exhibit consistent phase contrast across the catalyst, signifying the absence of metal particles in the catalyst. This was further confirmed by XRD analysis. As depicted in Figure 1d, the XRD pattern of BP-FeNC shows no crystalline phase other than the partly graphitized carbon, similar to BP. The pore structure of the catalyst was studied by BET analysis, showing the specific surface area of $565.3 \mathrm{~m}^{2} \mathrm{~g}^{-1}$, lower than that of BP $\left(1473.0 \mathrm{~m}^{2} \mathrm{~g}^{-1}\right)$. The pore size distribution is centered at $4 \mathrm{~nm}$ and $30 \mathrm{~nm}$, indicating the mesoporous structure of the newly formed phases in the catalyst. In a previous work, using the similar autoclave approach we synthesized a catalyst with very different structures, which were hollow spheres of graphitic layer encapsulated iron carbide nanoparticles.[30] The main difference in the synthesis between this work and the previous one is the addition of BP carbon support in the precursor, which leads to almost no metal particle formation in the obtained BP-FeNC catalyst. 
Besides BP, we have tried other carbon supports to synthesize the catalyst, including Ketjenblack EC-600J, graphitized Vulcan XC-72, and multi-walled carbon nanotubes. In all those syntheses, however, certain amounts of metal crystals were always found in the final catalysts, as revealed by XRD analysis (Figure S2). As such, the structure of carbon support must have played a significant role in determining the formation of metal particles in the synthesis.

To explore the active sites on the catalyst, XPS (Figure 2a-c) and STEM-EDS elemental mapping (Figure 2d-f) analysis were conducted. The XPS survey spectrum and further narrow scans of each element show the presence of $\mathrm{C}(93.33$ at. \%), N (3.07 at.\%), $\mathrm{O}(3.24$ at.\%), and Fe (0.27 at.\%) on the catalyst surface. Peak fitting of N 1s spectrum reveals mainly pyridinic N (42.24\%, at $398.33 \mathrm{eV})$ and graphitic $\mathrm{N}(39.44 \%$, at $400.81 \mathrm{eV})$, alongside a small amount of oxidized $\mathrm{N}(15.92 \%$, at 402.87 $\mathrm{eV}$ ) and pyrrolic $\mathrm{N}(2.39 \%$, at $399.45 \mathrm{eV})$. Although no consensus has been achieved thus far regarding the role of specific $\mathrm{N}$ species in $\mathrm{FeN}_{\mathrm{x}}$ active site structure, the importance of pyridinic $\mathrm{N}$ and graphitic $\mathrm{N}$ have been widely assumed.[14, 34, 35] The bulk iron content of BP-FeNC was determined by inductively coupled plasma-optical emission spectroscopy (ICP-OES) analysis, which was found to be $1.036 \mathrm{wt} \%$. Despite such a low iron content in the catalyst, elemental mapping images from the STEM-EDS analysis clearly show the uniform distribution of iron species (likely in atomic dispersion) across the catalyst (Figure 2 d-f), suggesting the uniform distribution of $\mathrm{FeN}_{\mathrm{x}}$ sites. In summary, we have synthesized a quite typical Fe-N-C catalyst, which contains uniformly distributed $\mathrm{FeN}_{\mathrm{x}}$ sites but no metal particles.

Next, the ORR performance of the catalyst was evaluated in three electrolytes: $\mathrm{HClO}_{4}, \mathrm{H}_{3} \mathrm{PO}_{4}$, and $\mathrm{HCl}$. They were prepared with the same $\mathrm{pH}$ value of 1.0. To avoid any other anion sources, the electrochemical cell was thoroughly cleaned before each test, and a RHE was used instead of SCE or $\mathrm{Ag} / \mathrm{AgCl}$ electrode. For comparison, a commercial $\mathrm{Pt} / \mathrm{C}$ was also tested and the result is discussed first. As shown in Figure 3a-c, the ORR activities of $\mathrm{Pt} / \mathrm{C}$ differ significantly in these three electrolytes. The mass-specific activity (at $0.9 \mathrm{~V}$ ) decreases in the order of $\mathrm{HClO}_{4}\left(304.2 \mathrm{~mA} \mathrm{mg}_{\mathrm{Pt}}{ }^{-1}\right)>$ $\mathrm{H}_{3} \mathrm{PO}_{4}\left(13.2 \mathrm{~mA} \mathrm{mg}{ }_{\mathrm{Pt}}^{-1}\right)>\mathrm{HCl}\left(\sim 0 \mathrm{~mA} \mathrm{mg}{ }_{\mathrm{Pt}}^{-1}\right)$. The smaller ORR diffusion limiting current in $\mathrm{H}_{3} \mathrm{PO}_{4}$ was mainly due to the higher electrolyte viscosity, lower oxygen solubility and smaller oxygen diffusion coefficient, while the smaller limiting current in $\mathrm{HCl}$ should be caused by the 
severe blocking effect of $\mathrm{Cl}^{-}$on Pt since it was not found in BP-FeNC tests (Figure 3d). [21, 30, 33, 36] The detrimental effect of anions on the ORR performance of Pt/C catalysts is well-known and has been extensively studied, which can be explained by the strong chemisorption of anions on the $\mathrm{Pt}$ surface.[21, 37-42] They are present on the Pt surface in the inner Helmholtz plane, generating the so-called "blocking effect", the extent of which is potential dependent (resulting in the typical two Tafel slopes, as shown in Figure S3 and Table S1) and varies with different Pt crystal facets.[43-47] Concerning Pt nanoparticles as in the Pt/C catalyst, which are rich of low-index facets (e.g. 100, 110, and 111), the observed performance sequence mainly reflects the adsorption strength of these anions on the low-index facets, i.e. $\mathrm{ClO}_{4}{ }^{-}<\mathrm{H}_{2} \mathrm{PO}^{-}<\mathrm{Cl}^{-}$. [21, 41, 43, 48]

As to the BP-FeNC catalyst, the obtained results were significantly different (Figure 3d-f). From the comparison between Figure 3a and 3d, one can see the BP-FeNC is less sensitive to anions than Pt/C, but the poisoning effect is still quite significant. The half-wave potential shift between that in $\mathrm{H}_{3} \mathrm{PO}_{4}$ and $\mathrm{HClO}_{4}$ is $34 \mathrm{mV}$, which increases to $74 \mathrm{mV}$ in $\mathrm{HCl}$. The mass-specific activity (at $0.8 \mathrm{~V}$ ) decreases from $8.6 \mathrm{~mA} \mathrm{mg}^{-1}$ in $\mathrm{H}_{3} \mathrm{PO}_{4}$ to $3.1 \mathrm{~mA} \mathrm{mg}^{-1}$ in $\mathrm{HClO}_{4}$, and further to $2.8 \mathrm{~mA} \mathrm{mg}^{-1}$ in $\mathrm{HCl}$, representing a $64 \%$ and $92 \%$ activity drop in $\mathrm{HClO}_{4}$ and $\mathrm{HCl}$, respectively. The higher activity of the catalyst in $\mathrm{H}_{3} \mathrm{PO}_{4}$ is obviously not from the higher electrolyte viscosity, lower oxygen solubility and smaller oxygen diffusion coefficient, which, on the contrary, should decrease the ORR kinetics to a certain extent. The only reasonable explanation is the stronger poisoning effect of $\mathrm{ClO}_{4}{ }^{-}$and $\mathrm{Cl}^{-}$than $\mathrm{H}_{2} \mathrm{PO}^{-}$. To check if this is a common property for this type of catalyst, we also tested a commercial Fe-N-C catalyst (NPC-2000 from Pajarito Powder), which showed very similar results with the activity in the order of $\mathrm{H}_{3} \mathrm{PO}_{4}>\mathrm{HClO}_{4}>\mathrm{HCl}$.

The poisoning effect of $\mathrm{ClO}_{4}{ }^{-}$on the catalyst was further confirmed by two sets of control experiments. One was testing the catalyst in $\mathrm{HClO}_{4}$ and inspecting the ORR activity change with the addition of various amounts of $\mathrm{H}_{3} \mathrm{PO}_{4}$, the other was done in the reverse manner, i.e. testing in $\mathrm{H}_{3} \mathrm{PO}_{4}$ with the addition of $\mathrm{HClO}_{4}$. As the starting point, $0.1 \mathrm{M} \mathrm{HClO}_{4}$ and $0.5 \mathrm{M} \mathrm{H}_{3} \mathrm{PO}_{4}$ were used since they had similar $\mathrm{pH}$ values close to 1 . Regarding the tests in $0.1 \mathrm{M} \mathrm{HClO}_{4}$ with various amounts of $\mathrm{H}_{3} \mathrm{PO}_{4}$ (Figure 4a), the ORR curves show almost no shift in the kinetic region (0.8-0.95 V) with the addition of $\mathrm{H}_{3} \mathrm{PO}_{4}$ up to $0.5 \mathrm{M}$, suggesting the poisoning effect of $\mathrm{H}_{2} \mathrm{PO}^{-}$is negligible 
on the catalyst. The gradually decreased limiting currents is obviously due to the increased $\mathrm{H}_{3} \mathrm{PO}_{4}$ concentration, causing the higher electrolyte viscosity, lower oxygen solubility and smaller oxygen diffusion coefficient, as already discussed above. In principle, this should cause slower ORR kinetics and negatively shifted curves, but likely the extent was too small to distinguish. As to the other set of tests, the results were much different. Figure $4 \mathrm{c}$ shows the ORR curves of BP-FeNC in $0.5 \mathrm{M} \mathrm{H}_{3} \mathrm{PO}_{4}$ with the addition of various amounts of $\mathrm{HClO}_{4}$. The almost unchanged limiting currents of the ORR curves indicate the viscosity, oxygen solubility and diffusion coefficient are largely unaffected by the addition $\mathrm{HClO}_{4}$ up to $0.1 \mathrm{M}$. Meanwhile, however, the ORR curves negatively shifted with the addition of $\mathrm{HClO}_{4}$. The half-wave potential shift is $11 \mathrm{mV}$ with the presence of $0.005 \mathrm{M} \mathrm{HClO}_{4}$, which further increases to $17 \mathrm{mV}, 24 \mathrm{mV}$, and $28 \mathrm{mV}$ for $0.01 \mathrm{M}, 0.05 \mathrm{M}$ and $0.1 \mathrm{M} \mathrm{HClO}_{4}$, respectively, confirming the poisoning effect of $\mathrm{ClO}_{4}{ }^{-}$on the catalyst. Alongside the changing in ORR activity, the addition of $\mathrm{HClO}_{4}$ also caused the change of $\mathrm{CVs}$ of the catalyst. As shown in Figure $4 \mathrm{~d}$, the CV intensities (i.e. the capacitance current) gradually increase with the addition of $\mathrm{HClO}_{4}$, which means the addition of $\mathrm{HClO}_{4}$ increases the electrochemical pseudocapacitance of the catalyst surface, a sign for specifically adsorbed ions $\left(\mathrm{ClO}_{4}{ }^{-}\right.$in this case $)$on the catalyst surface.[49] On the contrary, as shown in Figure 4b, the CVs of the catalyst exhibit no obvious change with the addition of $\mathrm{H}_{3} \mathrm{PO}_{4}$, suggesting the adsorption of $\mathrm{H}_{2} \mathrm{PO}^{-}$on the catalyst is negligible.

It's been widely assumed in literature that Fe-N-C catalysts are immune to anions, except for several Fe-related strong poisons such as $\mathrm{CN}^{-}$and $\mathrm{SCN}^{-} .[28,50]$ Obviously, it is not true on the basis of results from this work. Particularly, perchloric acid, the electrolyte that has been widely used for ORR characterizations, has a quite strong poisoning effect on the Fe-N-C catalysts. As indicated by the CV testing results shown in Figure 4, the origin of this poisoning effect is likely the adsorption of specific anions on the active sites, i.e. $\mathrm{FeN}_{\mathrm{x}}$ structure for the current understanding [14, 51]. Different from $\mathrm{Pt} / \mathrm{C}$, such adsorption might not be that strong to affect the rate-limiting step of ORR on the catalyst, reflected by the almost unchanged Tafel slopes obtained in the three electrolytes (Figure S2 and Table S1). To fully understand the mechanism of anion adsorption on $\mathrm{FeN}_{\mathrm{x}}$ sites, further exploration through experimental and computational studies is highly needed. 
Since the catalyst shows a negligible poisoning effect in $\mathrm{H}_{3} \mathrm{PO}_{4}$, it could be a good catalyst for high-temperature PEMFCs, where concentrated $\mathrm{H}_{3} \mathrm{PO}_{4}$ distributes throughout the electrodes. Before putting the catalyst into a fuel cell to test, we first checked the effect of $\mathrm{H}_{3} \mathrm{PO}_{4}$ concentration on the ORR performance of the catalyst. Figure 5 shows the ORR curves of both $\mathrm{Pt} / \mathrm{C}$ and $\mathrm{BP}-\mathrm{FeNC}$ in $\mathrm{H}_{3} \mathrm{PO}_{4}$ of different concentrations. We can see the kinetic region of ORR curves for Pt/C $(0.8-1.0 \mathrm{~V})$ shift negatively with increasing the $\mathrm{H}_{3} \mathrm{PO}_{4}$ concentration, and the $\mathrm{H}_{2} \mathrm{O}_{2}$ yields become higher, both indicating the stronger adsorption effect in more concentrated $\mathrm{H}_{3} \mathrm{PO}_{4}$. While for BP-FeNC, the ORR curves don't show an obvious shift in the kinetic region $(0.85-0.95 \mathrm{~V})$, and the $\mathrm{H}_{2} \mathrm{O}_{2}$ yields are even slightly lower in more concentrated $\mathrm{H}_{3} \mathrm{PO}_{4}$, confirming the negligible poisoning effect of phosphate anions on the BP-FeNC catalyst. In 5.0 M (i.e., $30.4 \mathrm{wt} \%$ ) $\mathrm{H}_{3} \mathrm{PO}_{4}$, the activity of the BP-FeNC has become higher than that of $20 \mathrm{wt} \% \mathrm{Pt} / \mathrm{C}$ (Figure 5a).

At last, high-temperature PEMFC tests were conducted for a demonstration. Polarization curves of single HT-PEMFC tests with $60 \mathrm{wt} \% \mathrm{Pt} / \mathrm{C}, 20 \mathrm{wt} \% \mathrm{Pt} / \mathrm{C}$ and BP-FeNC as the cathode catalyst are shown in Figure 6. Using $60 \mathrm{wt} \% \mathrm{Pt} / \mathrm{C}$, the cell shows a quite standard performance with the current density of $585.7 \mathrm{~mA} \mathrm{~cm}^{-2}$ at $0.60 \mathrm{~V}$ (Figure 6) and the maximum power density of $700 \mathrm{~mW} \mathrm{~cm}^{-2}$ (Figure S4).[8, 52, 53] With $20 \mathrm{wt} \% \mathrm{Pt} / \mathrm{C}$, the overall cell performance was reasonably lower due to the thicker catalyst layer. When BP-FeNC is employed, the cell performance is comparable to that with $\mathrm{Pt} / \mathrm{C}$ electrodes, especially in the low but practically operational current density range (> $0.6 \mathrm{~V})$, where the mass transport doesn't play a significant role. The peak power density is $184.6 \mathrm{~mW}$ $\mathrm{cm}^{-2}$ (Figure S4), and the current density at $0.6 \mathrm{~V}$ reaches $189.2 \mathrm{~mA} \mathrm{~cm}^{-2}$ (Figure 6). To the best of our knowledge, it is the highest performance ever reported for a high-temperature PEFMC using a NPMC in the cathode.[54]

\section{Conclusions}

In summary, we have investigated the effect of three common anions $\left(\mathrm{ClO}_{4}{ }^{-}, \mathrm{H}_{2} \mathrm{PO}^{-}\right.$, and $\left.\mathrm{Cl}^{-}\right)$on the ORR performance of a typical Fe-N-C catalyst. The catalyst was synthesized via a high-pressure pyrolysis in the presence of carbon support. As thoroughly characterized, it contained uniformly distributed $\mathrm{FeN}_{\mathrm{x}}$ functionalities but had no metal particles. When tested in $\mathrm{pH} 1.0 \mathrm{HClO}_{4}, \mathrm{H}_{3} \mathrm{PO}_{4}$ or $\mathrm{HCl}$ solution, the ORR activity at $0.8 \mathrm{~V}$ versus $\mathrm{RHE}$ decreased in order of $\mathrm{H}_{3} \mathrm{PO}_{4}\left(8.6 \mathrm{~mA} \mathrm{mg}^{-1}\right)>$ 
$\mathrm{HClO}_{4}\left(3.1 \mathrm{~mA} \mathrm{mg}^{-1}\right)>\mathrm{HCl}\left(0.69 \mathrm{~mA} \mathrm{mg}^{-1}\right)$. The activity drop was $64 \%$ from $\mathrm{H}_{3} \mathrm{PO} 4$ to $\mathrm{HClO}_{4}$, and $92 \%$ from $\mathrm{H}_{3} \mathrm{PO}_{4}$ to $\mathrm{HCl}$. The same tests with a commercial Fe-N-C catalyst (NPC-2000 from Pajarito Powder) showed very similar results. The poisoning effect observed in $\mathrm{HClO}_{4}$, as well as $\mathrm{HCl}$, is attributed to the strong adsorption of the acid anions on the active sites of the catalysts, as further confirmed by tests with varied $\mathrm{ClO}_{4}{ }^{-}$concentrations. This finding is of special significance by considering the fact that $\mathrm{HClO}_{4}$ has been widely used in ORR tests of $\mathrm{Fe}-\mathrm{N}-\mathrm{C}$ catalysts. On the other hand, the catalyst showed a negligible poisoning effect in $\mathrm{H}_{3} \mathrm{PO}_{4}$, even in the concentrated form of $30.4 \mathrm{wt} \%$. It suggests an obvious application of the type of NPMC in high-temperature PEMFCs, where concentrated $\mathrm{H}_{3} \mathrm{PO}_{4}$ distributes throughout the electrodes. As demonstrated, the catalyst did show excellent performance in high-temperature PEFMC tests, comparable to Pt/C catalysts.

\section{Acknowledgements}

We gratefully acknowledge financial support from the Danish ForskEL program (UPCAT,2015-1-12315) and Innovation Fund Denmark (4M Centre, 12-132710 and NonPrecious, 4106-00012B).

\section{References:}

[1]http://money.cnn.com/2017/07/26/autos/countries-that-are-banning-gas-cars-forelectric/index.htm 1.

[2]https://www.bloomberg.com/news/articles/2017-09-10/china-s-fossil-fuel-deadline-shifts-focus-to -electric-car-race-j7fktx9z.

[3] M.K. Debe, Electrocatalyst approaches and challenges for automotive fuel cells, Nature, 486 (2012) 43-51.

[4] A. Rabis, P. Rodriguez, T.J. Schmidt, Electrocatalysis for Polymer Electrolyte Fuel Cells: Recent Achievements and Future Challenges, Acs Catalysis, 2 (2012) 864-890.

[5] H.A. Gasteiger, N.M. Markovic, Just a Dream-or Future Reality?, Science, 324 (2009) 48-49.

[6] B.C.H. Steele, A. Heinzel, Materials for fuel-cell technologies, Nature, 414 (2001) 345-352.

[7] J. Zhang, Z. Xie, J. Zhang, Y. Tang, C. Song, T. Navessin, Z. Shi, D. Song, H. Wang, D.P. Wilkinson, Z.-S. Liu, S. Holdcroft, High temperature PEM fuel cells, Journal of Power Sources, 160 (2006) 872-891.

[8] A. Chandan, M. Hattenberger, A. El-kharouf, S. Du, A. Dhir, V. Self, B.G. Pollet, A. Ingram, W. Bujalski, High temperature (HT) polymer electrolyte membrane fuel cells (PEMFC) - A review, 
Journal of Power Sources, 231 (2013) 264-278.

[9] Y. Nie, L. Li, Z. Wei, Recent advancements in Pt and Pt-free catalysts for oxygen reduction reaction, Chemical Society Reviews, 44 (2015) 2168-2201.

[10] F. Jaouen, E. Proietti, M. Lefevre, R. Chenitz, J.-P. Dodelet, G. Wu, H.T. Chung, C.M. Johnston, P. Zelenay, Recent advances in non-precious metal catalysis for oxygen-reduction reaction in polymer electrolyte fuel cells, Energy \& Environmental Science, 4 (2011) 114-130.

[11] Z. Chen, D. Higgins, A. Yu, L. Zhang, J. Zhang, A review on non-precious metal electrocatalysts for PEM fuel cells, Energy \& Environmental Science, 4 (2011) 3167-3192.

[12] Z.H. Xia, L. An, P.K. Chen, D.G. Xia, Non-Pt Nanostructured Catalysts for Oxygen Reduction Reaction: Synthesis, Catalytic Activity and its Key Factors, Advanced Energy Materials, 6 (2016).

[13] M. Shao, Q. Chang, J.-P. Dodelet, R. Chenitz, Recent Advances in Electrocatalysts for Oxygen Reduction Reaction, Chem. Rev., 116 (2016) 3594-3657.

[14] H.T. Chung, D.A. Cullen, D. Higgins, B.T. Sneed, E.F. Holby, K.L. More, P. Zelenay, Direct atomic-level insight into the active sites of a high-performance PGM-free ORR catalyst, Science, 357 (2017) 479-484.

[15] J. Shui, C. Chen, L. Grabstanowicz, D. Zhao, D.-J. Liu, Highly efficient nonprecious metal catalyst prepared with metal-organic framework in a continuous carbon nanofibrous network, Proceedings of the National Academy of Sciences, 112 (2015) 10629-10634.

[16] M. Lefevre, E. Proietti, F. Jaouen, J.P. Dodelet, Iron-Based Catalysts with Improved Oxygen Reduction Activity in Polymer Electrolyte Fuel Cells, Science, 324 (2009) 71-74.

[17] E. Proietti, F. Jaouen, M. Lefevre, N. Larouche, J. Tian, J. Herranz, J.-P. Dodelet, Iron-based cathode catalyst with enhanced power density in polymer electrolyte membrane fuel cells, Nature Communications, 2 (2011).

[18] S.K. Zecevic, J.S. Wainright, M.H. Litt, S.L. Gojkovic, R.F. Savinell, Kinetics of O 2 Reduction on a Pt Electrode Covered with a Thin Film of Solid Polymer Electrolyte, J. Electrochem. Soc., 144 (1997) 2973-2982.

[19] V. Stamenkovic, T.J. Schmidt, P.N. Ross, N.M. Markovic, Surface composition effects in electrocatalysis: Kinetics of oxygen reduction on well-defined Pt3Ni and Pt3Co alloy surfaces, J. Phys. Chem. B, 106 (2002) 11970-11979.

[20] M. Nesselberger, S. Ashton, J.C. Meier, I. Katsounaros, K.J.J. Mayrhofer, M. Arenz, The Particle Size Effect on the Oxygen Reduction Reaction Activity of Pt Catalysts: Influence of Electrolyte and Relation to Single Crystal Models, J. Am. Chem. Soc., 133 (2011) 17428-17433.

[21] T.J. Schmidt, U.A. Paulus, H.A. Gasteiger, R.J. Behm, The oxygen reduction reaction on a $\mathrm{Pt} /$ carbon fuel cell catalyst in the presence of chloride anions, Journal of Electroanalytical Chemistry, 508 (2001) 41-47.

[22] N. Markovic, P.N. Ross, The effect of specific adsorption of ions and underpotential deposition of copper on the electro-oxidation of methanol on platinum single-crystal surfaces, Journal of Electroanalytical Chemistry, 330 (1992) 499-520.

[23] N. Markovic, M. Hanson, G. McDougall, E. Yeager, The effects of anions on hydrogen electrosorption on platinum single-crystal electrodes, Journal of Electroanalytical Chemistry and Interfacial Electrochemistry, 214 (1986) 555-566.

[24] A. Berná, V. Climent, J.M. Feliu, New understanding of the nature of $\mathrm{OH}$ adsorption on $\mathrm{Pt}(111)$ electrodes, Electrochemistry Communications, 9 (2007) 2789-2794. 
[25] G.E. Dima, A.C.A. de Vooys, M.T.M. Koper, Electrocatalytic reduction of nitrate at low concentration on coinage and transition-metal electrodes in acid solutions, Journal of Electroanalytical Chemistry, 554-555 (2003) 15-23.

[26] W.G. Pell, A. Zolfaghari, B.E. Conway, Capacitance of the double-layer at polycrystalline Pt electrodes bearing a surface-oxide film, Journal of Electroanalytical Chemistry, 532 (2002) 13-23.

[27] R. Subbaraman, D. Strmcnik, V. Stamenkovic, N.M. Markovic, Three Phase Interfaces at Electrified Metal-Solid Electrolyte Systems 1. Study of the Pt(hkl)-Nafion Interface, The Journal of Physical Chemistry C, 114 (2010) 8414-8422.

[28] Q. Wang, Z.-Y. Zhou, Y.-J. Lai, Y. You, J.-G. Liu, X.-L. Wu, E. Terefe, C. Chen, L. Song, M. Rauf, N. Tian, S.-G. Sun, Phenylenediamine-Based FeNx/C Catalyst with High Activity for Oxygen Reduction in Acid Medium and Its Active-Site Probing, J. Am. Chem. Soc., 136 (2014) 10882-10885.

[29] D. Malko, A. Kucernak, T. Lopes, Performance of Fe-N/C Oxygen Reduction Electrocatalysts toward NO2-, NO, and NH2OH Electroreduction: From Fundamental Insights into the Active Center to a New Method for Environmental Nitrite Destruction, J. Am. Chem. Soc., 138 (2016) 16056-16068.

[30] Y. Hu, J.O. Jensen, W. Zhang, L.N. Cleemann, W. Xing, N.J. Bjerrum, Q. Li, Hollow Spheres of Iron Carbide Nanoparticles Encased in Graphitic Layers as Oxygen Reduction Catalysts, Angewandte Chemie International Edition, 53 (2014) 3675-3679.

[31] A. Chandan, M. Hattenberger, A. El-Kharouf, S.F. Du, A. Dhir, V. Self, B.G. Pollet, A. Ingram, W. Bujalski, High temperature (HT) polymer electrolyte membrane fuel cells (PEMFC) - A review, Journal of Power Sources, 231 (2013) 264-278.

[32] M. Mamlouk, K. Scott, The effect of electrode parameters on performance of a phosphoric acid-doped PBI membrane fuel cell, International Journal of Hydrogen Energy, 35 (2010) 784-793.

[33] Q. Li, G. Wu, D.A. Cullen, K.L. More, N.H. Mack, H.T. Chung, P. Zelenay, Phosphate-Tolerant Oxygen Reduction Catalysts, ACS Catalysis, 4 (2014) 3193-3200.

[34] U.I. Kramm, J. Herranz, N. Larouche, T.M. Arruda, M. Lefevre, F. Jaouen, P. Bogdanoff, S. Fiechter, I. Abs-Wurmbach, S. Mukerjee, J.P. Dodelet, Structure of the catalytic sites in $\mathrm{Fe} / \mathrm{N} / \mathrm{C}$-catalysts for O-2-reduction in PEM fuel cells, Phys. Chem. Chem. Phys., 14 (2012) 11673-11688.

[35] G. Wu, C.M. Johnston, N.H. Mack, K. Artyushkova, M. Ferrandon, M. Nelson, J.S. Lezama-Pacheco, S.D. Conradson, K.L. More, D.J. Myers, P. Zelenay, Synthesis-structure-performance correlation for polyaniline-Me-C non-precious metal cathode catalysts for oxygen reduction in fuel cells, J. Mater. Chem., 21 (2011) 11392-11405.

[36] M.J. Fleige, G.K.H. Wiberg, M. Arenz, Rotating disk electrode system for elevated pressures and temperatures, Review of Scientific Instruments, 86 (2015) 064101.

[37] D. Strmcnik, K. Kodama, D. van der Vliet, J. Greeley, V.R. Stamenkovic, N.M. Markovic, The role of non-covalent interactions in electrocatalytic fuel-cell reactions on platinum, Nature Chemistry, 1 (2009) 466-472.

[38] D.V. Tripkovic, D. Strmcnik, D. van der Vliet, V. Stamenkovic, N.M. Markovic, The role of anions in surface electrochemistry, Faraday Discussions, 140 (2009) 25-40.

[39] T.M. Arruda, B. Shyam, J.M. Ziegelbauer, S. Mukerjee, D.E. Ramaker, Investigation into the 
Competitive and Site-Specific Nature of Anion Adsorption on Pt Using In Situ X-ray Absorption Spectroscopy, The Journal of Physical Chemistry C, 112 (2008) 18087-18097.

[40] J.X. Wang, N.M. Markovic, R.R. Adzic, Kinetic Analysis of Oxygen Reduction on Pt(111) in Acid Solutions: Intrinsic Kinetic Parameters and Anion Adsorption Effects, The Journal of Physical Chemistry B, 108 (2004) 4127-4133.

[41] N.M. Marković, P.N. Ross, Surface science studies of model fuel cell electrocatalysts, Surf. Sci. Rep., 45 (2002) 117-229.

[42] N.M. Marković, T.J. Schmidt, V. Stamenković, P.N. Ross, Oxygen Reduction Reaction on Pt and Pt Bimetallic Surfaces: A Selective Review, Fuel Cells, 1 (2001) 105-116.

[43] A. Kolics, A. Wieckowski, Adsorption of Bisulfate and Sulfate Anions on a Pt(111) Electrode, The Journal of Physical Chemistry B, 105 (2001) 2588-2595.

[44] N.M. Markovic, H.A. Gasteiger, B.N. Grgur, P.N. Ross, Oxygen reduction reaction on Pt(111): effects of bromide, Journal of Electroanalytical Chemistry, 467 (1999) 157-163.

[45] J. Perez, H.M. Villullas, E.R. Gonzalez, Structure sensitivity of oxygen reduction on platinum single crystal electrodes in acid solutions, Journal of Electroanalytical Chemistry, 435 (1997) 179-187.

[46] N.M. Markovic, H.A. Gasteiger, P.N. Ross, Oxygen Reduction on Platinum Low-Index Single-Crystal Surfaces in Sulfuric Acid Solution: Rotating Ring-Pt(hkl) Disk Studies, The Journal of Physical Chemistry, 99 (1995) 3411-3415.

[47] F. El Kadiri, R. Faure, R. Durand, Electrochemical reduction of molecular oxygen on platinum single crystals, Journal of Electroanalytical Chemistry and Interfacial Electrochemistry, 301 (1991) 177-188.

[48] Q. He, X. Yang, W. Chen, S. Mukerjee, B. Koel, S. Chen, Influence of phosphate anion adsorption on the kinetics of oxygen electroreduction on low index Pt(hkl) single crystals, Phys. Chem. Chem. Phys., 12 (2010) 12544-12555.

[49] Y.-H. Lee, K.-H. Chang, C.-C. Hu, Differentiate the pseudocapacitance and double-layer capacitance contributions for nitrogen-doped reduced graphene oxide in acidic and alkaline electrolytes, Journal of Power Sources, 227 (2013) 300-308.

[50] M.S. Thorum, J.M. Hankett, A.A. Gewirth, Poisoning the Oxygen Reduction Reaction on Carbon-Supported $\mathrm{Fe}$ and $\mathrm{Cu}$ Electrocatalysts: Evidence for Metal-Centered Activity, J. Phys. Chem. Lett., 2 (2011) 295-298.

[51] A. Zitolo, V. Goellner, V. Armel, M.-T. Sougrati, T. Mineva, L. Stievano, E. Fonda, F. Jaouen, Identification of catalytic sites for oxygen reduction in iron- and nitrogen-doped graphene materials, Nat. Mater., 14 (2015) 937-942.

[52] Q.F. Li, J.O. Jensen, R.F. Savinell, N.J. Bjerrum, High temperature proton exchange membranes based on polybenzimidazoles for fuel cells, Prog. Polym. Sci., 34 (2009) 449-477.

[53] M. Mamlouk, K. Scott, An investigation of Pt alloy oxygen reduction catalysts in phosphoric acid doped PBI fuel cells, Journal of Power Sources, 196 (2011) 1084-1089.

[54] Y. Hu, J.O. Jensen, W. Zhang, S. Martin, R. Chenitz, C. Pan, W. Xing, N.J. Bjerrum, Q. Li, Fe3C-based oxygen reduction catalysts: synthesis, hollow spherical structures and applications in fuel cells, Journal of Materials Chemistry A, 3 (2015) 1752-1760. 


\section{Figures:}

a)

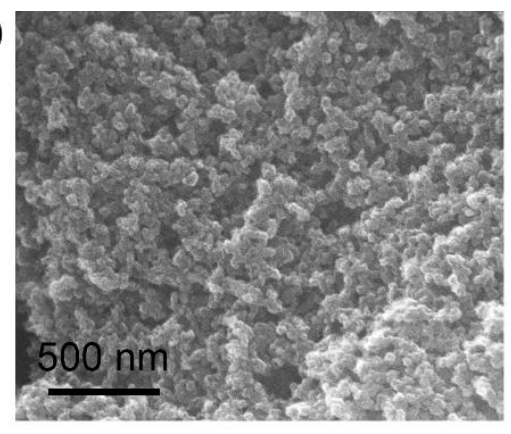

b)

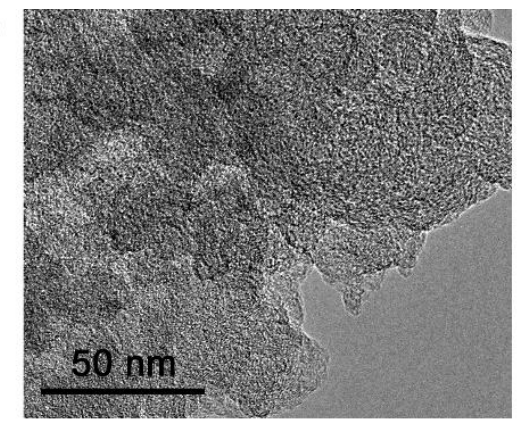

d)

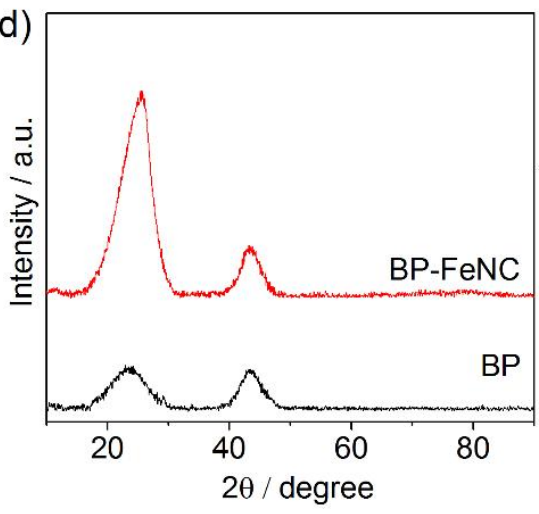

e)

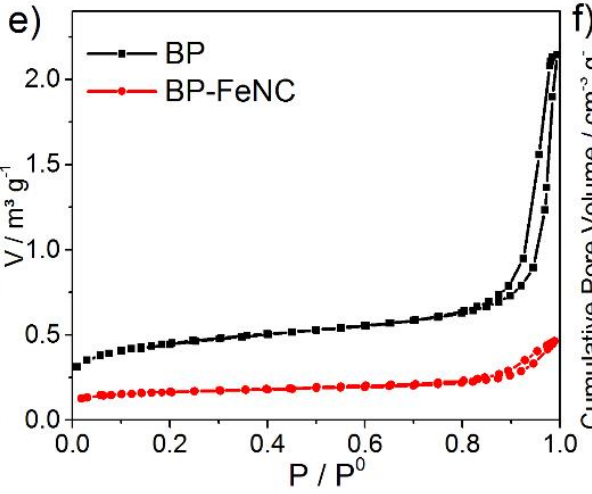

c)
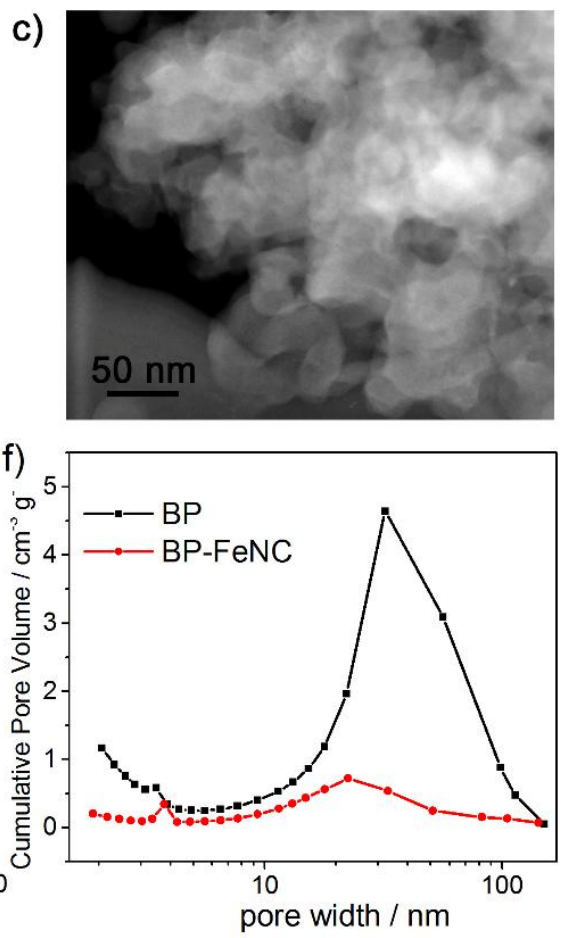

Figure 1. Structural characterization of the BP-FeNC catalyst. a) SEM, b) TEM, and c) HAADF-STEM images of BP-FeNC. d) XRD patterns of BP and BP-FeNC. e) Nitrogen adsorption and desorption isotherms of BP and BP-FeNC. The BET surface areas of BP and BP-FeNC are 1473.0 and $565.3 \mathrm{~m}^{2} \mathrm{~g}^{-1}$, respectively.. f) BJH pore-size distribution of BP and BP-FeNC derived from BET measurements. 

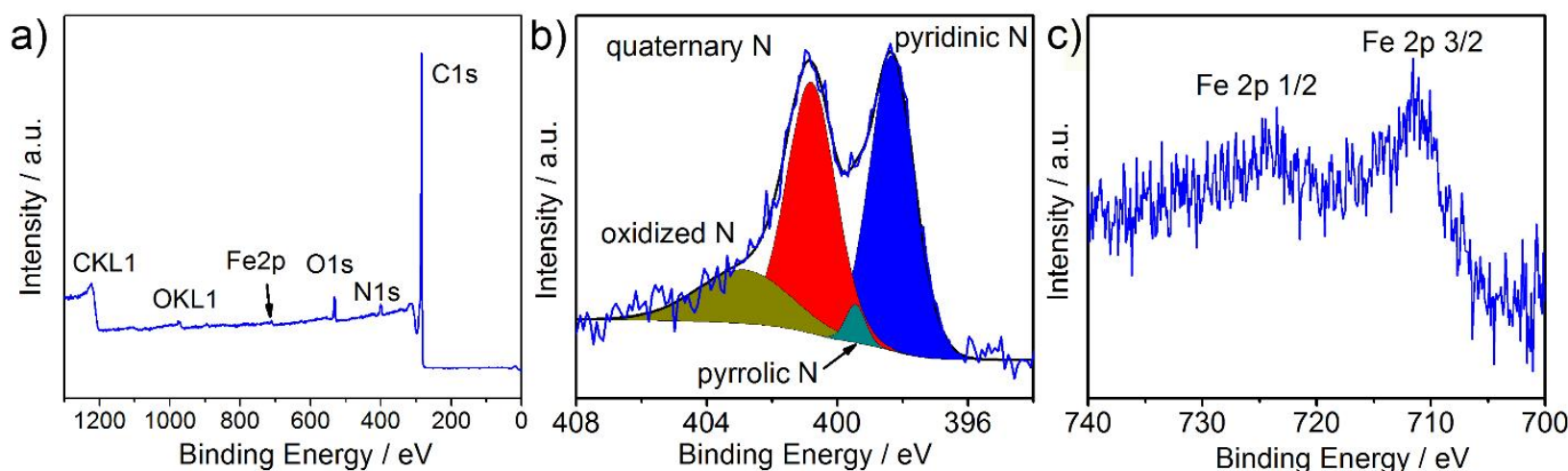

d)
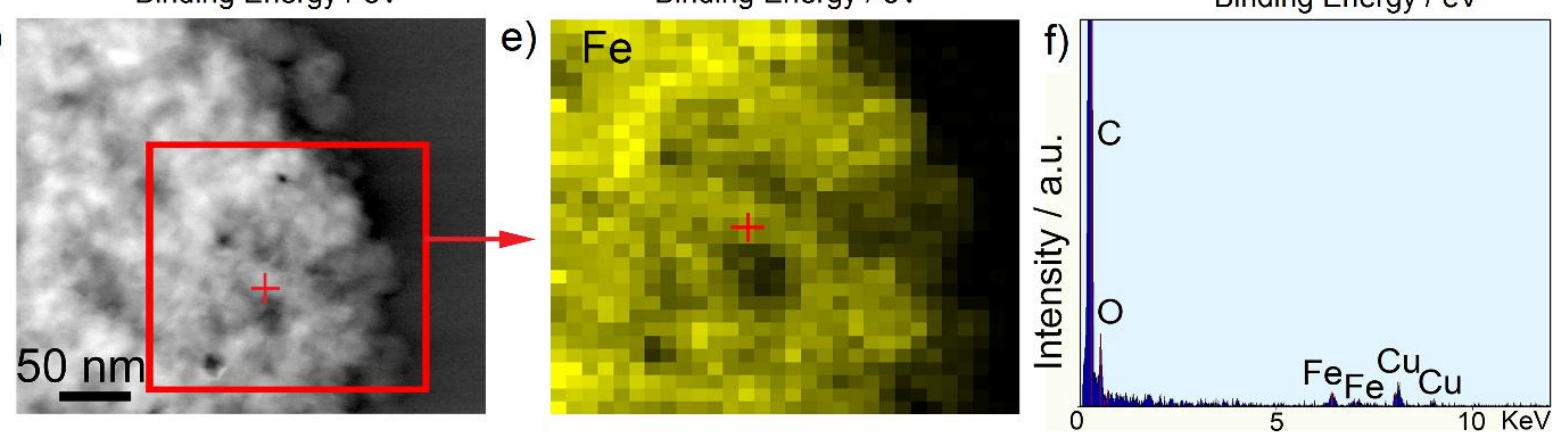

Figure 2: Active site exploration of the BP-FeNC catalyst. a) XPS survey spectrum. b,c) High-resolution XPS spectra of $\mathrm{N}$ 1s with the peak deconvolution (b) and Fe 2p (c). d-f) HAADF-STEM image (d) and the corresponding elemental mapping of Fe-K (e) as well as the EDS point analysis on the spot marked with red crosses on the images (f). The $\mathrm{Cu}$ signal originates from the TEM grid. 

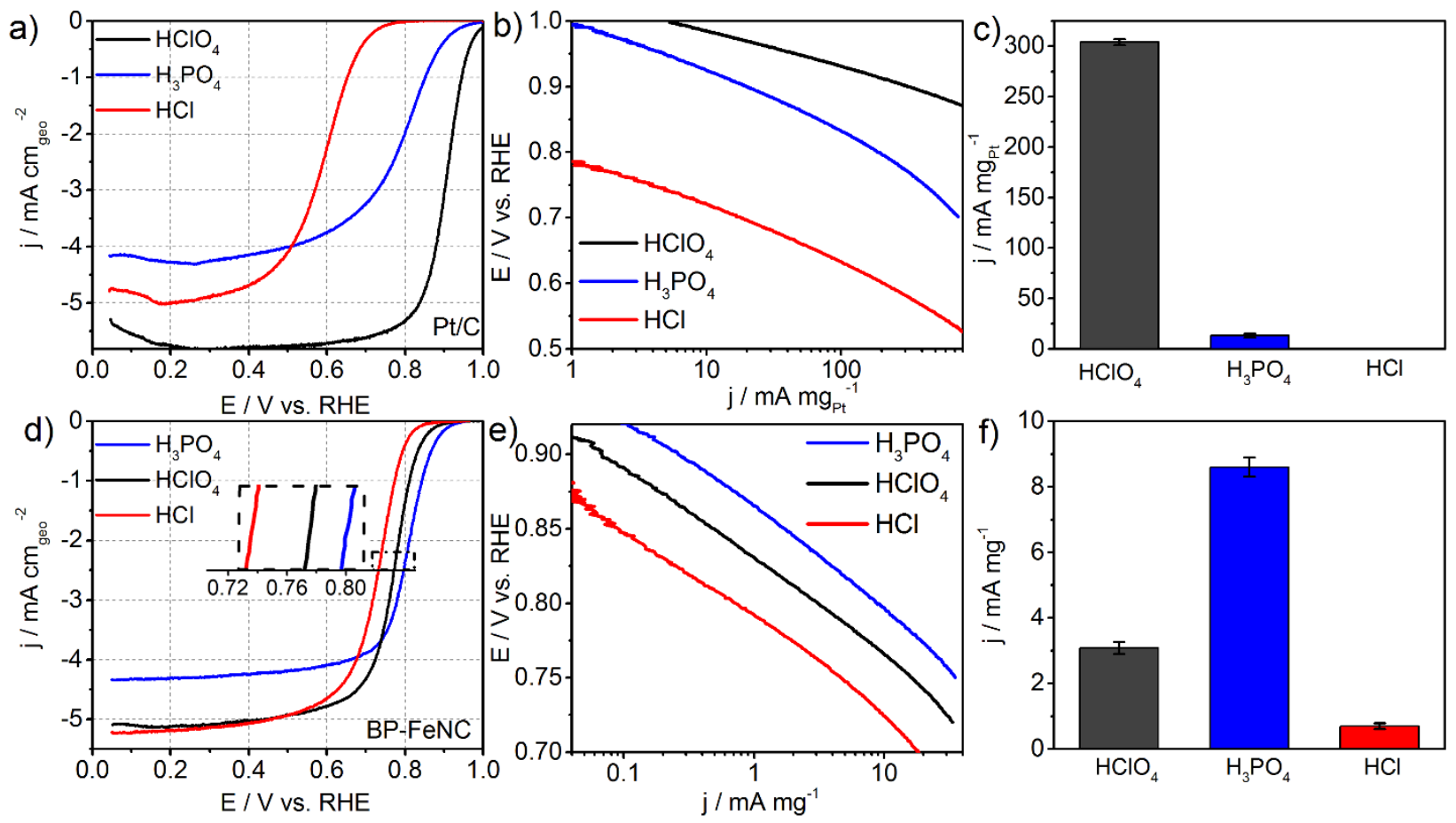

Figure 3: ORR characterizations of $\mathrm{Pt} / \mathrm{C}$ and $\mathrm{BP}-\mathrm{FeNC}$ in $\mathrm{pH} 1.0 \mathrm{HClO}_{4}, \mathrm{H}_{3} \mathrm{PO}_{4}$ and $\mathrm{HCl}$ solutions. a-c) ORR polarization curves (anodic scans), Tafel plots, and mass-specific activities (at $0.9 \mathrm{~V}$ ) of $20 \mathrm{wt} \% \mathrm{Pt} / \mathrm{C}$ (from Johnson Matthey). Catalyst loading: $20 \mu \mathrm{g}_{\mathrm{Pt}} \mathrm{cm}^{-2}$; Rotation rate: 1600 rpm; Scan rate: $10 \mathrm{mV} \mathrm{s}^{-1}$. d-f) ORR polarization curves (cathodic scans), Tafel plots and mass-specific activities (at $0.8 \mathrm{~V}$ ) of BP-FeNC. Catalyst loading: $600 \mu \mathrm{g} \mathrm{cm}^{-2}$; Rotation rate: 1600 $\mathrm{rpm}$; Scan rate: $10 \mathrm{mV} \mathrm{s}^{-1}$. Error bars in (c) and (f) show the standard deviation of each data point from at least three independent measurements. To minimize the error in Tafel analysis, only the ORR currents below $80 \%$ of the diffusion limiting currents were used. 

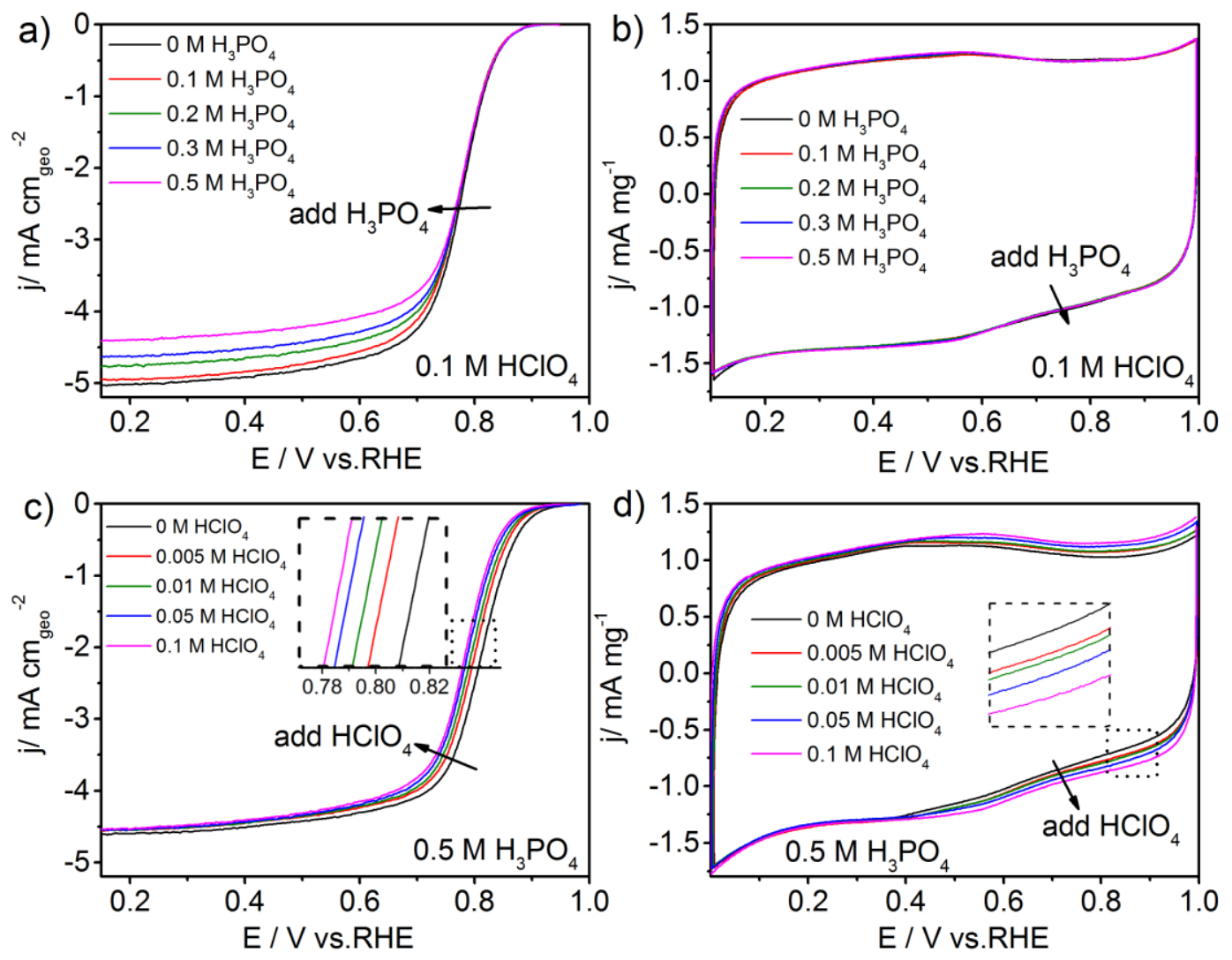

Figure 4: a) ORR polarization curves (cathodic scans) of $\mathrm{BP}-\mathrm{FeNC}$ in $0.1 \mathrm{M} \mathrm{HClO}_{4}$ with the addition of various amounts of $\mathrm{H}_{3} \mathrm{PO}_{4}$. b) The corresponding $\mathrm{CVs}$ of BP-FeNC in the Ar-saturated electrolytes. c) ORR polarization curves (cathodic scans) of BP-FeNC in $0.5 \mathrm{M} \mathrm{H}_{3} \mathrm{PO}_{4}$ with the addition of various amounts of $\mathrm{HClO}_{4}$. d) The corresponding CVs of BP-FeNC in the Ar-saturated electrolytes. Catalyst loading: $600 \mu \mathrm{g} \mathrm{cm}^{-2}$; Scan rate: $10 \mathrm{mV} \mathrm{s}^{-1}$; Rotation rate for ORR curves: 1600 rpm. 

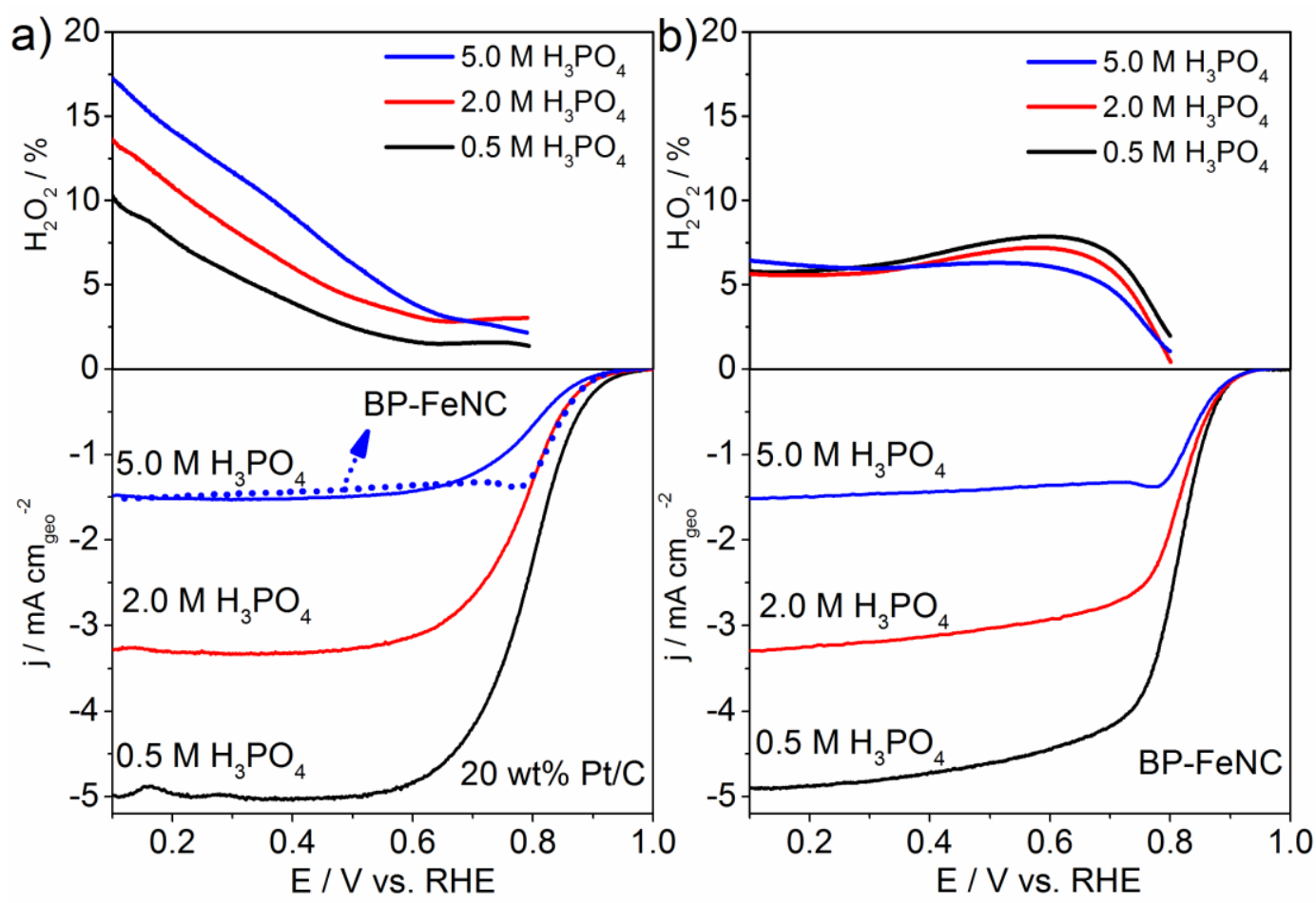

Figure 5: a) ORR polarization curves (cathodic scans, bottom) and $\mathrm{H}_{2} \mathrm{O}_{2}$ yield plots (top) of 20 wt $\%$ $\mathrm{Pt} / \mathrm{C}$ in $\mathrm{H}_{3} \mathrm{PO}_{4}$ solutions of different concentrations. Catalyst loading: $20 \mu \mathrm{g}_{\mathrm{Pt}} \mathrm{cm}^{-2}$; Rotation rate: $1600 \mathrm{rpm}$; Scan rate: $10 \mathrm{mV} \mathrm{s}^{-1}$. For comparison, the ORR curve of BP-FeNC in $5.0 \mathrm{M} \mathrm{H}_{3} \mathrm{PO}_{4}$ (the dotted line) is also included. b) ORR polarization curves (cathodic scans, bottom) and $\mathrm{H}_{2} \mathrm{O}_{2}$ yield plots (top) of BP-FeNC in $\mathrm{H}_{3} \mathrm{PO}_{4}$ solutions of different concentrations. Catalyst loading: $600 \mu \mathrm{g} \mathrm{cm}^{-2}$; Rotation rate: $1600 \mathrm{rpm}$; Scan rate: $10 \mathrm{mV} \mathrm{s}^{-1}$. 


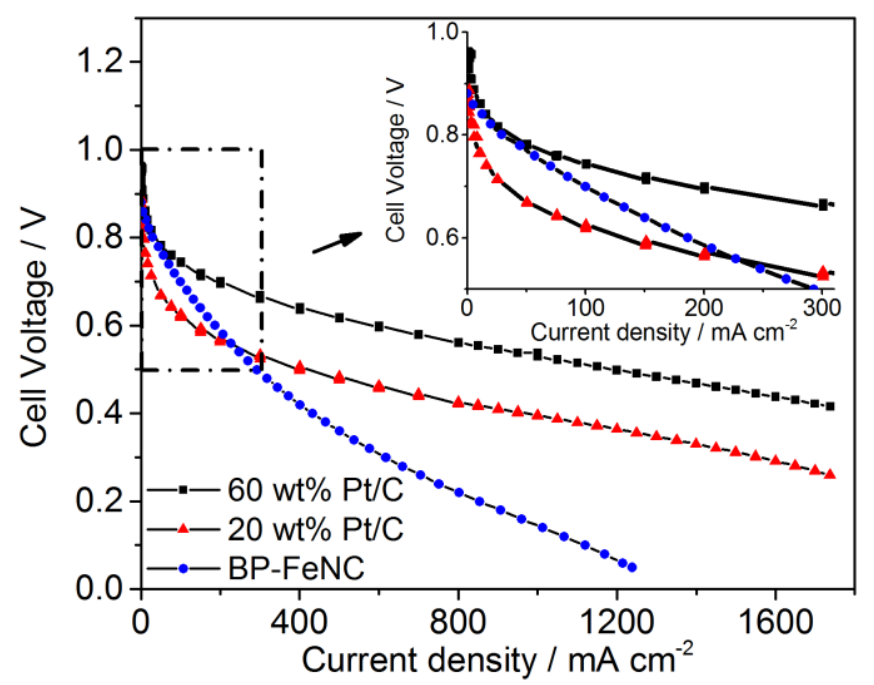

Figure 6: Polarization curves of $\mathrm{H}_{2}-\mathrm{O}_{2}$ high-temperature PEMFC tests at $160{ }^{\circ} \mathrm{C}$ with $60 \mathrm{wt} \% \mathrm{Pt} / \mathrm{C}$ $\left(2.7 \mathrm{mg} \mathrm{cm}^{-2}\right.$ or $\left.1.6 \mathrm{mg}_{\mathrm{Pt}} \mathrm{cm}^{-2}\right), 20 \mathrm{wt} \% \mathrm{Pt} / \mathrm{C}\left(4.4 \mathrm{mg} \mathrm{cm}^{-2}\right.$ or $\left.0.88 \mathrm{mg}_{\mathrm{Pt}} \mathrm{cm}^{-2}\right)$, and BP-FeNC (7.8 mg $\mathrm{cm}^{-2}$ ) as the cathode catalyst without iR correction (see Experimental section and Table 1 for the details).

Table 1. Experimental parameters for HT-PEMFC tests.

\begin{tabular}{|c|c|c|c|}
\hline & $\begin{array}{l}\text { Catalyst loading } \\
\left(\mathrm{mg} \mathrm{cm}^{-2}\right)\end{array}$ & $\begin{array}{l}\mathrm{PBI} / \text { catalyst } / \mathrm{H}_{3} \mathrm{PO}_{4} \quad(\mathrm{wt} \%) \\
\text { in the cathode }\end{array}$ & $\begin{array}{l}\text { Gas flow (mL } \mathrm{min}^{-1} \\
\left.\mathrm{~cm}^{-2}\right): \mathrm{O}_{2} / \mathrm{H}_{2}\end{array}$ \\
\hline $60 \mathrm{wt} \% \mathrm{Pt} / \mathrm{C}$ & $2.7\left(1.6_{\mathrm{Pt}}\right)$ & $1 / 35.0 / 0$ & $20 / 20$ \\
\hline $20 \mathrm{wt} \% \mathrm{Pt} / \mathrm{C}$ & $4.4\left(0.88_{\mathrm{Pt}}\right)$ & $1 / 8.8 / 10$ & $20 / 20$ \\
\hline BP-FeNC & 7.8 & $1 / 8.5 / 10$ & $20 / 20$ \\
\hline
\end{tabular}




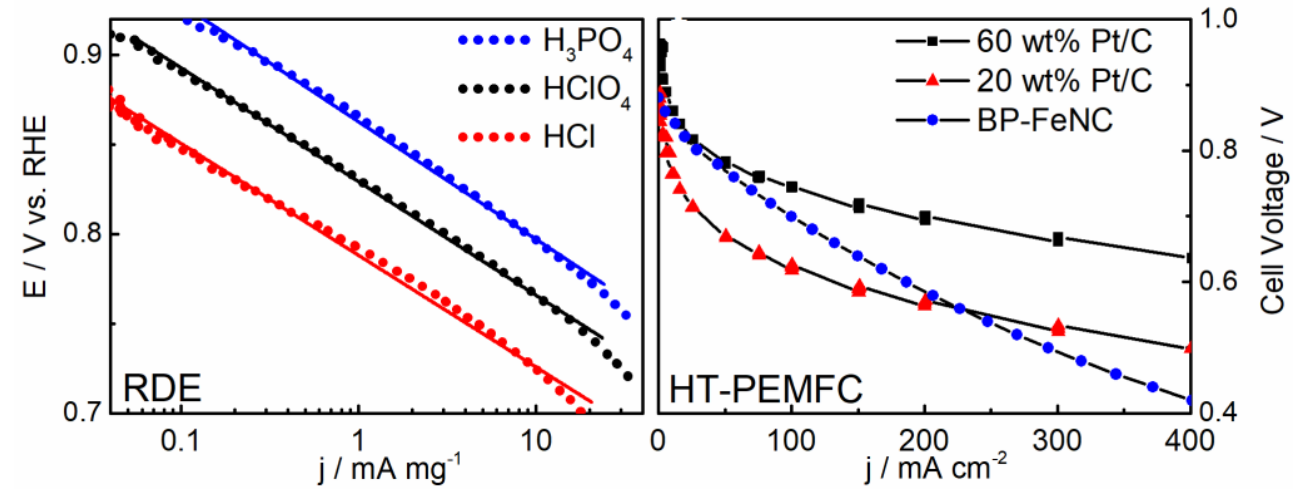

